\title{
APPLICATION OF DIFFERENTIATED MODERN TECHNOLOGIES TO DIFFERENT TYPES OF RETAIL TRADE: CURRENT REALITY AND PROSPECTS
}

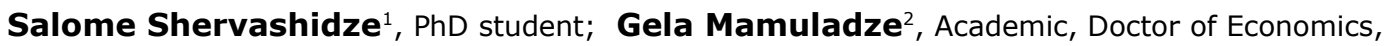 \\ Professor \\ ${ }^{1,2}$ Batumi Shota Rustaveli State University
}

\begin{abstract}
In the conditions of accelerated globalization, based on improving internal organizational and marketing solutions and rationalizing market behavior, new models of commercial enterprise management are being introduced. Given the current market development trends, the retailer must not only solve problems related to the physical distribution of goods, but also fight in fierce competition for customers. One of the main reasons for increasing competition is the large number of retail businesses, such as small businesses, large chain markets, department stores etc. Each of them occupies a niche that must be maintained by its own forces. Thus, the retailer must take into account many factors and make appropriate strategic and tactical decisions in the development of its business. In this article, the example of Georgia evaluates the attitude of customers to retail stores and analyzes the General factors that affect this fact. The aim of this paper is to make an investigation of above mentioned relationship and lead to the further modernization of the retail sales strategies. Customers usually go to regular stores to make purchases, despite the increased availability of orders made online or by mobile phone. A large number of end users want to participate in the procurement process themselves, even though modern technologies are actively used in the procurement process.

Based on empirical research and statistical analysis, the relationship between the type of priority procurement object and modern technologies used in the procurement process was revealed. Based on this assessment, we can conclude which types of technology development and interaction will be beneficial for owners of different types of retail outlets. Mobile apps have leadership position in any type of retail business, with the exception of fairs, where $70 \%$ of customers receive information from social networks. Unfortunately, auxiliary bots still are not used by Georgian customers as simplifying tool of procurement process

With the development of existing forms of modern retail trade, new forms are being introduced into the market. For successful realization of the finished product, for retail industry leaders it is a necessary requirement to understand modern internet methods and techniques of sale, as stated in the results of the study retailers should give preference to mobile apps.
\end{abstract}

Key words: retail Ssales, purchasing, modern technologies, competition, priority purchasing. JEL code: M30, M31

\section{Introduction}

In modern socio-economic conditions, the role of retailers has increased much more than in previous years, which is mainly due to the development of new marketing technologies. In a tough competition traders must win and strengthen their place in the target market segment. The emergence of international retail chains in local markets increases competition between retailers and increases the importance of key strategies in the process of gaining competitive advantages, improving marketing tools and innovations.

Retailers need faster and more professional maneuvering of existing resources to develop modern commerce. Various studies have shown that price is a key factor in the buying process (Owusu A., 2013), but people don't want to give up the quality, convenience, and enjoyable buying process because of the price. Retail sales are characterized by impulsive purchases, and resellers, on the contrary, make purchases systematically.

In each segment of the market, customers create an image of the institution for themselves, guided by what they consider subjectively more important than others. American scientists J. Engell and R. Blackwell, commenting on this hypothesis, describe the process of perception and choice of a

1 Salome Shervashidze e-mail: Salome.shervashihdze@gmail.com 
business institution with such details as location, assortment, prices, advertising and incentives, quality of service and level of training of service personnel (Engell J., Bleckwell R., 2001).

The success or failure of a retail establishment is largely determined by the customer's attitude towards it. Customer loyalty is mainly formed by subjective evaluation, which is formed in the subconscious of the same customer. In this regard, any commercial institution should be considered not only from a functional point of view, but also from the basic psychological aspects (Kotler Ph., Keller K., 2013).

While the market often creates problems for particularly small retailers, it is not difficult for most establishments that are well prepared to do business to compete with larger firms. In the process of analyzing the situation, retailers who are planning their strategy or refining it should especially think about their capabilities. Obviously, misjudged views about their capabilities, resources, competitors and opportunities can lead to disastrous results.

Despite the recent increased availability of ordering online or by phone, customers usually go to regular stores to make purchases. A large number of end users want to participate in the purchasing process themselves, because these end users need to know about the sales pitch, and it is very important to have the right lure strategy (Simonson I., 2005).

Customers quickly refer to a particular merchant when asking which store they are referring to, naming features such as "lowest price", "most convenient", "best service", and so on. It should be noted that the most prominent and popular institutions for a specific target segment are usually mentioned in the answers. Thus, the more the actual image of the merchant is presented to the customer, the more increases the psychological willingness to make a purchase at that object.

For the purpose of this study, we have considered the following retail outlets: small area stores, mini markets, chain supermarkets, hypermarkets, and fairs, while identifying as used modern technologies mobile applications, QR codes, social networks and auxiliary bots accordingly.

The following methods were used in the research process: data collection and statistical analysis. Quantitative research strategy was used for the research. The questionnaire was developed and posted on the web and was available from 1 November 2010 to 28 January 2020, 356 users were surveyed, due to incomplete information we ignored 26 user-filled responses and reviewed responses from 330 respondents.

\section{Research results and discussion}

Habits have a big impact on customer behavior. Some customers prefer large supermarkets, others-small home stores, third-party - exhibitions / sales. Each of them is based on their own experience of buying goods, covering all aspects of the relationship between the buyer and the seller.

Currently, at the revival stage of online trading in Georgia, we get a rather strange picture of the issue of determining the purchase path. The quantitative research design was used in the study and the quantitative survey of the costumers was conducted via google forms. Vast majority of our respondents ( $93.6 \%$ ) still buy goods physically, $4.8 \%$ use online stores, and only $1.5 \%$ use certain online shopping sites (Figure 1). This fact can be explained by the desire of costumers to participate in the procurement process itself, to compare different models and trademarks, to be emotionally involved in the procurement process; however, this desire also does not exclude the use of modern technologies in the procurement process at any stage of it. 
Source: author's calculations based on the results of the survey

Fig. 1. Customers' attitude towards procurement

According to the survey results (Figure 2), chain supermarkets actually lead the way (46.7 \%).

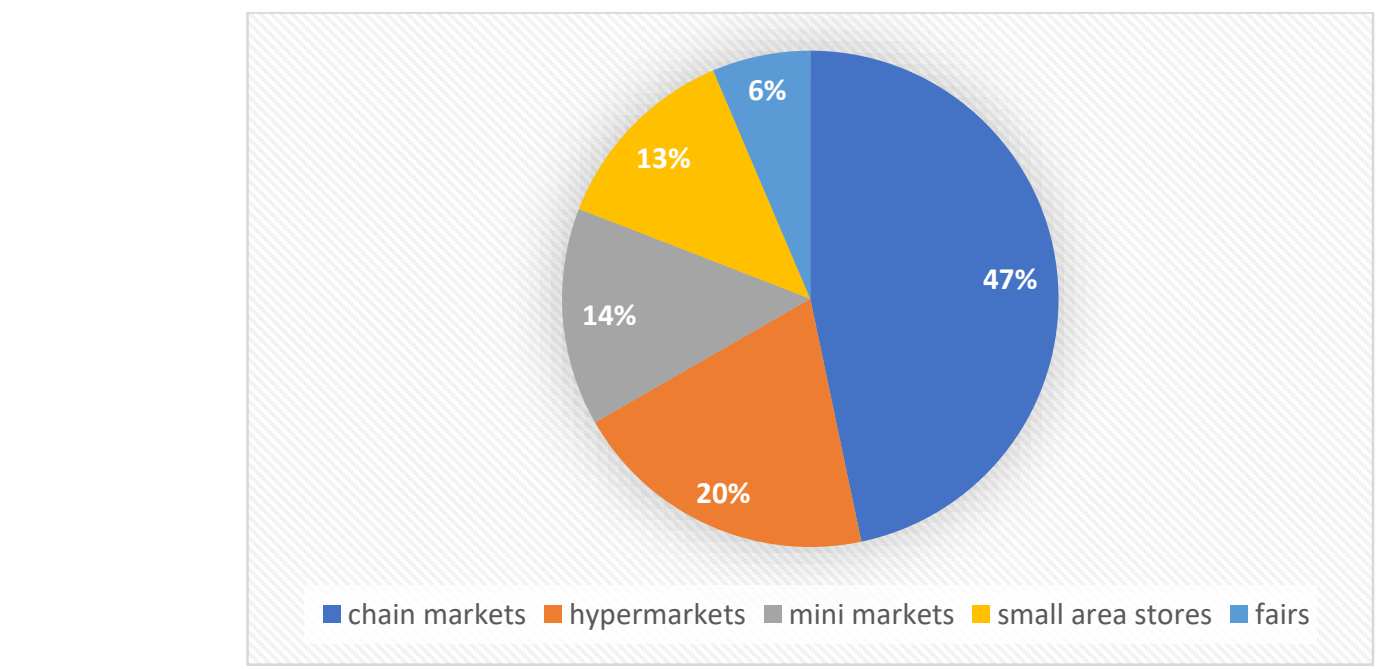

Source: author's calculations based on the results of the survey

Fig. 2. Customer attitude towards physical retail trade object

Both rational and emotional factors influence the purchase decision (Achar, C., So, J., Agrawal, N., \& Duhachek, A. 2016). In any case, it depends on the decision maker, the procurement object, and various aspects that affect him. Based on a complex analysis of the factors that influence the decision to buy a product, this decision of the Georgian customer is determined by the selfservice, which is in the chain supermarkets, the customer is free from the attention of the specific sales representative, which does not coincide with the modern trends, where the active sales representative should be more favored. This is where we need to look for one of the key problems in the retail business.

From a retailer's perspective, online space and modern technologies can perform several functions, including image display and information delivery to potential customers as well as simplifying the procurement process (Pontano, E., Nguyen. B., Dennis, C., Gerlach, S., 2016). The performance of this task depends on the goals of the organization.

The widespread adoption of mobile technologies and the Internet has furthered the development of the retail markets and has even shaped the global market development trends for several years. The concept of "modern commerce", which emerged in the 1980s, when large retail chains were solely at the expense of pricing policies, paid little attention to personal communication with customers. At present, however, the situation is opposite - communication is the basis of a 'knowledge economy' where the foreground is not the products themselves but the customer service process (OECD, 2001). 
With the evolution of business models, manufacturers and sellers connect directly with customers online. The use of modern technologies in the procurement process is largely driven by the integration of online and offline sites, personalized offers and discounts, innovative payment methods, automated logistics solutions. Considering the use of the latest technologies by research participants at various stages of the procurement process as a stimulating factor, $70 \%$ of our respondents use at least some of the modern technologies (Figure 3).

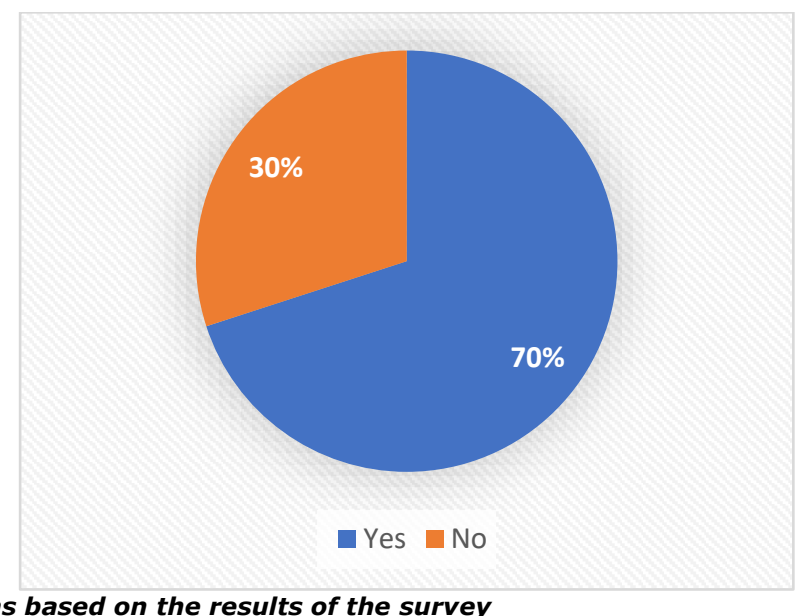

Source: author's calculations based on the results of the survey

Fig. 3. Usage of modern technologies in the procurement process

Respondents of this study had groups and pages on social network, mobile apps, auxiliary bots, QR codes to choose from among the used modern technologies The majority of users (77.4\%) favour mobile applications, which allows us to assume that this is where retailers should focus their attention. By itself, knowing only which technology is used most in the procurement process does not provide us with comprehensive information that the supplier can use, unless we specifically determine which type of facility customers prefer.

For this purpose, in accordance with the Chi Square method, we examined the relationship between the type of procurement object and the technology used. We got P-value less than 0.05, therefore we concluded, that between these two variables there is a significant statistical relationship. The results are shown in Table 1. 
Application of modern technologies to the type of procurement object

\begin{tabular}{|c|c|c|c|c|c|}
\hline \multirow{2}{*}{\multicolumn{2}{|c|}{ Type of procurement object }} & \multicolumn{3}{|c|}{ Used modern technology } & \multirow{3}{*}{$\begin{array}{c}\text { Total } \\
34\end{array}$} \\
\hline & & \multirow{2}{*}{$\begin{array}{c}\begin{array}{c}\text { Mobile } \\
\text { app }\end{array} \\
20\end{array}$} & \multirow{2}{*}{$\begin{array}{c}\text { QR } \\
4 \\
\end{array}$} & \multirow{2}{*}{$\begin{array}{c}\begin{array}{c}\text { Soc. } \\
\text { networks }\end{array} \\
10 \\
\end{array}$} & \\
\hline \multirow{3}{*}{ Small area stores } & Count & & & & \\
\hline & $\%$ preferable procurement object & $58.8 \%$ & $11.8 \%$ & $29.4 \%$ & $100.0 \%$ \\
\hline & $\begin{array}{l}\% \text { used modern technology in } \\
\text { procurement process }\end{array}$ & $12.4 \%$ & $16.7 \%$ & $15.6 \%$ & $13.7 \%$ \\
\hline \multirow{3}{*}{ Minimarkets } & Count & 18 & 4 & 6 & 28 \\
\hline & $\%$ preferable procurement object & $64.3 \%$ & $14.3 \%$ & $21.4 \%$ & $100.0 \%$ \\
\hline & $\begin{array}{l}\% \text { used modern technology in } \\
\text { procurement process }\end{array}$ & $11.2 \%$ & $16.7 \%$ & $9.4 \%$ & $11.2 \%$ \\
\hline \multirow{3}{*}{$\begin{array}{l}\text { Chain } \\
\text { supermarkets }\end{array}$} & Count & 78 & 10 & 28 & 116 \\
\hline & $\%$ preferable procurement object & $67.2 \%$ & $8.6 \%$ & $24.1 \%$ & $100.0 \%$ \\
\hline & $\begin{array}{l}\% \text { used modern technology in } \\
\text { procurement process }\end{array}$ & $48.4 \%$ & $41.7 \%$ & $43.8 \%$ & $46.6 \%$ \\
\hline \multirow{3}{*}{ Hypermarkets } & Count & 39 & 6 & 13 & 58 \\
\hline & $\%$ preferable procurement object & $67.2 \%$ & $10.3 \%$ & $22.4 \%$ & $100.0 \%$ \\
\hline & $\begin{array}{l}\% \text { used modern technology in } \\
\text { procurement process }\end{array}$ & $24.2 \%$ & $25.0 \%$ & $20.3 \%$ & $23.3 \%$ \\
\hline \multirow[b]{3}{*}{ Fairs } & Count & 3 & 0 & 7 & 10 \\
\hline & $\%$ preferable procurement object & $30.0 \%$ & $0.0 \%$ & $70.0 \%$ & $100.0 \%$ \\
\hline & $\begin{array}{l}\% \text { used modern technology in } \\
\text { procurement process }\end{array}$ & $1.9 \%$ & $0.0 \%$ & $10.9 \%$ & $4.0 \%$ \\
\hline \multirow{3}{*}{ Total } & Count & 158 & 24 & 64 & 246 \\
\hline & $\%$ preferable procurement object & $64.7 \%$ & $9.6 \%$ & $25.7 \%$ & $100.0 \%$ \\
\hline & $\begin{array}{l}\% \text { used modern technology in } \\
\text { procurement process }\end{array}$ & $100.0 \%$ & $\begin{array}{c}100.0 \\
\%\end{array}$ & $100.0 \%$ & $100.0 \%$ \\
\hline
\end{tabular}

Source: author's calculations based on the results of the survey

According to the Table 1, of those who favor small-area marketers, $58.8 \%$ use mobile apps, $11.8 \%$ QR code, and 29.4 social network groups and pages.

Most of the supermarkets' customers( $64.3 \%$ ) use mobile apps; $14.3 \%$ use QR code and $21.4 \%$ social networking groups, respectively.

Most of the users of network supermarkets (67.2\%) use mobile apps, $8.6 \%$ use QR code and $24.1 \%$ social network groups.

Most hypermarket customers (67.2 \%) use of mobile apps, $10.3 \%$ use QR codes and $22.4 \%$ social networking groups.

As for fairs, $30 \%$ of users use this mobile app only and $70 \%$ use social networking groups and pages.

By analyzing the research data and spreadsheet, we can boldly identify the undisputed leadership of mobile apps in any type of merchant, with the exception of fairs where $70 \%$ of customers receive information from social networking groups and webpages before purchasing. Also, one of the latest trends for our respondents, auxiliary bots, are not yet a simplifying tool in the procurement process.

\section{Conclusions, proposals, recommendations}

The success or failure of a retail trading company is determined by the customer's attitude towards it. Customer loyalty is mostly subjective, emotional assessment is formed, it should be noted that in the light of the changes that are taking place in social and economic life, the retail institutions are 
forced to maintain their competitiveness in the market to fully consider customer micro and macroeconomic conditions, including the following.

1) To maintain a stable market position, retailers must carefully select the target market and position it correctly, determining the exact competitive advantage and selecting the type of trade.

2) The rapid growth in the number of smartphones and other related devices, combined with widespread international access, has become a prerequisite for the revival of mobile commerce in Georgia. According to the results of this study, retailers should give preference to mobile apps for their products.

3) Social networks have introduced new approaches to the retail sector in principle. Providers have received databases that can provide a personalized offer for users, so groups and social media pages should be used not only to provide information, but also to plan products and services.

4) For the successful realization of the finished product for retail industry, for leaders and staff it is a necessary condition to understand modern internet methods and techniques of sale. Technology helps sellers to optimize their supply chains, diversify their communication channels, and enter new markets

5) Although the use of QR codes and auxiliary bots is less common among our respondents, considering global trends, they have a great potential for development, thus we should pay more attention to the involvement of technology in the procurement process.

6) Georgian internet companies should try to gain trust, offer discounts, prices should be more attractive for customers to feel benefits from internet purchases.

\section{Bibliography}

1. Achar, C., So, J., Agrawal, N., \& Duhachek, A. (2016). What We Feel and Why We Buy: The Influence of Emotions on Consumer Decision-Making. Current Opinion in Psychology, 10, 166170. https://doi.org/10.1016/j.copsyc.2016.01.009

2. Chi, H, K., Yeh, H, R., Huang, M, W. (2008). The Influences of Advertising Endorser, Brand Image, Brand Equity, Price Promotion, on Purchase Intention the Mediating Effect of Advertising Endorser, Taiwan.

3. Engell, J., Blackwell, R., Miniard, P. (2001). Consumer Behavior. 9th ed. Ft. Worth. Harcourt College Publishers. New York

4. Hislop, M. (2001). An Overview of Branding and Brand Measurement for Online Marketers. Dynamic Logic's Branding, Vol. 101, pp. 1-22

5. Kotler, Ph., Keller, K. L., Koshy, A., Jha, M. (2013). Marketing Management: A South Asian Perspective, 14thEdition.

6. OECD, 2001 Competencies for The Knowledge Economy

7. Owusu, A. (2013). Influences of Price and Quality On Consumer Purchase of Mobile Phone In The Kumasi Metropolis In Ghana A Comparative Study (179-184) European Journal of Business and Management Vol.5, No.1, 2013

8. Pontano, E., Nguyen. B., Dennis, C., Gerlach, S. (2016). Internet Retailing and Future Perspectives Routledge, Taylor and Francis Group, London.

9. Simonson, I (2005). Determinants of Customers' Responses to Customized Offers: Conceptual Framework and Research Propositions. Retrived:https://journals.sagepub.com/doi/10.1509/jmkg.69.1.32.55512, Access: 19.02 .2020 